\title{
The Association of MMP7 Genotype With Pterygium
}

\author{
PEI-SHIN HU ${ }^{1,2,3 *}$, YUN-CHI WANG ${ }^{3 *}$, CHENG-HSI LIAO ${ }^{1,3,4^{*}}$, NING-YI HSIA ${ }^{3,5}$, MENG-FENG WU $^{1,3,4}$ \\ JAI-SING YANG ${ }^{3}$, CHIEN-CHIH YU ${ }^{3}$, WEN-SHIN CHANG ${ }^{3}$, DA-TIAN BAU ${ }^{1,3,6}$ and CHIA-WEN TSAI ${ }^{3}$ \\ ${ }^{1}$ Graduate Institute of Biomedical Sciences, China Medical University, Taichung, Taiwan, R.O.C.; \\ ${ }^{2}$ Department of Ophthalmology, Changhua Christian Hospital, Changhua, Taiwan, R.O.C.; \\ ${ }^{3}$ Terry Fox Cancer Research Laboratory, Translational Medicine Center, \\ China Medical University Hospital, Taichung, Taiwan, R.O.C.; \\ ${ }^{4}$ National Defense Medical Center, Taipei, Taiwan, R.O.C.; \\ ${ }^{5}$ Department of Ophthalmology, China Medical University Hospital, Taichung, Taiwan, R.O.C.; \\ ${ }^{6}$ Department of Bioinformatics and Medical Engineering, Asia University, Taichung, Taiwan, R.O.C.
}

\begin{abstract}
Background/Aim: In literature, few studies have examined the diagnostic or prognostic potential of matrix metalloproteinases (MMP) in pterygium, whose formation and progression are closely related to imbalance in the extracellular microenvironment. In this study, we investigated the contribution of MMP7 promoter (A-181G and C-153T) polymorphic genotypes to pterygium risk. Materials and Methods: A total of 134 cases and 268 controls were collected and their MMP7 genotypes at $A-181 G$ and $C-153 T$ were examined by polymerase chain reaction-restriction fragment length polymorphism methodology. Results: The AA, AG and $G G$ genotypes at MMP7 promoter A-181G were nonsignificantly differentially distributed between the two groups at $85.8,11.2$ and $3.0 \%$, respectively, in pterygium cases and 88.4, 9.7 and $1.9 \%$ in controls, respectively ( $p$ for trend $=0.6822$ ). There was no polymorphic genotype for MMP7 C-153T among our Taiwanese cohort. Conclusion: $A-181 G$ and $C-153 T$ genotypes at MMP7 do not have a direct role in determining Taiwanese susceptibility to pterygium.
\end{abstract}

This article is freely accessible online.

*These Authors contributed equally to this study.

Correspondence to: Da-Tian Bau, Chia-Wen Tsai and Wen-Shin Chang, Terry Fox Cancer Research Laboratory, China Medical University Hospital, 2 Yuh-Der Road, Taichung, 404 Taiwan, R.O.C. Tel: +886 422053366 Ext. 5805, e-mail: artbau2@gmail.com (Bau DT); wenwen816@gmail.com (Tsai CW); halittlemelon@hotmail.com (Chang WS)

Key Words: Age, gender, genotype, $M M P 7$, polymorphism, pterygium, Taiwan.
Pterygium is a disease presenting an abnormal wing-shaped outgrowth of fibrovascular conjunctival tissues invading the clear cornea. The etiology of pterygium is still largely unclear. The incidence of pterygium is epidemiologically due to several factors, such as overexposure to sunshine, UV light, heat, dust, and other particles in the atmosphere (1-3). In the past two decades, mounting evidence has supported the concept that variations in our genome play a critical role in the determination of the etiology and development of pterygium (4-11). Many theories for pterygium have been proposed, such as imbalances in immunological mechanisms, growth factors, cytokines, apoptosis, angiogenesis (12-15), and most interestingly but complicatedly, an imbalance in the extracellular microenvironment and the involvement of matrix metalloproteinases (MMPs) (16-19).

MMPs are a group of zinc-binding endopeptidases responsible for regulating the components of the extracellular matrix microenvironment (20). The activation of MMPs generally takes place in the extracellular space, and interacts with various other proteases, teaming up to regulate the behaviors of cancer cells including viability, cell differentiation, programmed cell death, angiogenesis, immune surveillance, invasiveness and migration capacity $(21,22)$.

The smallest MMP member, MMP7 (matrilysin), is responsible for the metabolism of a broad spectrum of substrates including fibronectin, vitronectin, elastin, collagen IV, aggrecan, and proteoglycans (23). In addition, MMP7 is involved in inflammatory responses via its capacity to promote cell-surface processing of cytokines such as tumor necrosis factor a (24). MMP7 activation was first proposed to be involved in the pathogenesis of pterygium as early as 2001 by Girolamo and colleagues (25). In their analysis of cultured pterygial and conjunctival tissues from eight pterygium cases at Wales hospital in Sydney, basal and activated MMP7 levels were 1.4- and 2.7-fold higher, respectively, in pterygia 
compared with conjunctiva (25). In 2007, Kato and colleagues examined the mRNA expression of the $\beta$-catenindriven gene MMP7 in pterygial and corneal limbal epithelium, and found that MMP7 was uniquely expressed in all of the four pterygium samples examined (26). They were also interested in investigating the contribution of MMP7 to pterygium at the DNA level, however, their limited sample size was unsuitable for that purpose.

Since the two promoter polymorphic sites of $M M P 7, \mathrm{~A}-$ $181 \mathrm{G}$ and $\mathrm{C}-153 \mathrm{~T}$, may be in charge of controlling the level of MMP7 expression, we aimed to examine the association of $M M P 7 \mathrm{~A}-181 \mathrm{G}$ and $\mathrm{C}-153 \mathrm{~T}$ polymorphisms with the susceptibility to pterygium in the current study.

\section{Materials and Methods}

Collection of patients with pterygium and selection of controls. The well-designed protocol of the investigation was approved by the Institutional Review Board of Changhua Christian Hospital (number: 151225) and written informed consent was obtained from all of the patients. In total, 134 pterygium cases were recruited into the current study with the help of all the colleagues in Department of Ophthalmology at Changhua Christian Hospital in central Taiwan. All of the clinical characteristics for each of the patient such as their histological and surgical records, were identified by at least two expert surgeons at Changhua Christian Hospital. All of the pterygium cases voluntarily took in part, completed a questionnaire (containing personal age, gender, life-style and environmental exposure, etc.), and provided 3 to $5 \mathrm{ml}$ of their peripheral blood. The inclusion criteria for the pterygium cases were the science of the apex of the pterygium invading the cornea by at least $1 \mathrm{~mm}$. For the control group, all of those enrolled were healthy volunteers aged 45 years or more without pterygium or any type of cancer who visited the Department of Ophthalmology at Changhua Christian Hospital. In the final pool, the case group included 78 males and 56 females (age range of 48 to 89 years, with an average age of 64.4 years). Finally, 268 healthy participants without pterygium and without cancer were selected in order to match the population structure of the pterygium population (we doubled the number of cases and matched for their ages and genders). The overall agreement rate in the sampling of both the case and control groups was more than $85 \%$. Selected basal characteristics of both the pterygium and control groups are presented in Table I.

Methodology for determining MMP7 genotypes. Genomic DNA from peripheral blood leukocytes of each participant was carefully extracted within $12 \mathrm{~h}$ after sample collection, then aliquoted and stored as we previously described (27). The MMP7 genotyping methodology is the same as our recently published article (28). The genotyping polymerase chain reaction (PCR) cycling conditions via My Cycler (Biorad, Hercules, CA, USA) for $M M P 7$ were set as: one cycle at $94^{\circ} \mathrm{C}$ for $5 \mathrm{~min} ; 35$ cycles of $94^{\circ} \mathrm{C}$ for $30 \mathrm{~s}, 57^{\circ} \mathrm{C}$ for $30 \mathrm{~s}$ and $72^{\circ} \mathrm{C}$ for $30 \mathrm{~s}$; a final extension at $72^{\circ} \mathrm{C}$ for $10 \mathrm{~min}$; kept at $25^{\circ} \mathrm{C}$ if needed overnight.

Methodology for statistical analysis. Typical Pearson's chi-square test without Yates' correction (when all frequencies were $\geq 5$ ) and
Fisher's exact test (when any number was less than 5) was applied to compare the distribution of gender, and $M M P 7$ genotypes and alleles between the two groups. The unpaired Student's $t$-test was applied for the comparison of distribution of the ages between the two groups. The associations between the MMP7 genotypes and allelic types with the risk for pterygium were estimated by evaluating the odds ratios (ORs) as well as their $95 \%$ confidence intervals (CIs) using unconditional logistic regression with adjustment for possible confounding factors including age and gender.

\section{Results}

Comparison of age and gender between the patient and control groups. The percentage of males and females was $58.2 \%$ and $41.8 \%$ in both groups. Since we matched the age and gender when recruiting the controls into the study, there was no significant difference between the two groups regarding these data, as expected $(p>0.05)$ (Table I).

Association analysis of MMP7 A-181G and C-153T promoter genotypes with pterygium risk. The results of PCR-RFLP-based genotypic analysis of the MMP7 promotor A-181G and C-153T among the pterygium cases and controls are presented and compared in Table II. Firstly, the genotypic frequency distributions for MMP7 A$181 \mathrm{G}$ did not statistically differ between the groups ( $p$ for trend=0.6822) (Table II). In detail, the MMP7 A-181G heterozygous AG and homozygous GG genotypes seemed not to be associated with risk for pterygium among Taiwanese (adjusted $\mathrm{OR}=1.11$ and $1.28,95 \% \mathrm{CI}=0.56-2.21$ and $0.47-5.36 ; p=0.6141$ and 0.4844 , respectively; Table II). Even combining the G-carrying genotypes to compare with the AA genotype, risk for pterygium was unaltered ( $p=0.4544$ ) (Table II). Secondly, we noted that there were no bearers of the polymorphic genotype at MMP7 C-153T among any of the examined Taiwanese subjects (Table II). Overall, MMP7 A-181G and C-153T genotypes do not play a direct role in determining personal susceptibility to pterygium among Taiwanese.

Association analysis of MMP7 A-181G and C-153T allelic frequencies with pterygium risk. We have further conducted the allelic frequency analysis for MMP7 promoter A-181G and C-153T with pterygium risk to confirm the findings in Table II, and the results are shown in Table III. Supporting the preliminary findings in Table II, there was still no differential distribution of the allelic frequencies between the pterygium and control groups for the MMP7 A-181G site (Table III). The adjusted OR for those carrying the variant $\mathrm{G}$ allele at $M M P 7$ promoter A-181G was $1.34(95 \% \mathrm{CI}=0.77$ 2.32, $p=0.3389$ ), compared to those carrying the wild-type A allele (Table III). As for the analysis of allelic frequency for MMP7 C-153T, there was no association between the 
Table I. Distribution of selected demographics of the 134 pterygium patients and the 268 non-pterygium controls.

\begin{tabular}{llccc}
\hline Characteristic & & Controls (n=268) & Patients (n=134) & $p$-Value \\
\hline Age at onset, years & Mean \pm SD & $64.3 \pm 6.0$ & $64.4 \pm 7.0$ & $0.9660^{\mathrm{a}}$ \\
Gender, n (\%) & Male & $156(58.2 \%)$ & $78(58.2 \%)$ & $>0.99 \mathrm{~b}$ \\
& Female & $112(41.8 \%)$ & $56(41.8 \%)$ & \\
\hline
\end{tabular}

SD: Standard deviation. aStudent's $t$-test; bchi-square test.

Table II. Distribution of matrix metalloproteinase (MMP7) A-181G and C-153T genotypic frequencies among patients with pterygium and healthy controls.

\begin{tabular}{lccc}
\hline MMP7 polymorphism & Patients, $\mathrm{n}(\%)$ & Controls, $\mathrm{n}(\%)$ & ${\text { Adjusted OR }(95 \% \mathrm{CI})^{\mathrm{a}}}$-Value $^{\mathrm{b}}$ \\
\hline A-181G & & & 1.00 (Reference) \\
AA & $115(85.8)$ & $237(88.4)$ & $1.11(0.56-2.21)$ \\
AG & $15(11.2)$ & $26(9.7)$ & $1.28(0.47-5.36)$ \\
GG & $4(3.0)$ & $5(1.9)$ & $1.19(0.49-2.64)$ \\
AG+GG & $19(14.2)$ & $31(11.6)$ & -- \\
$p_{\text {trend }}$ & & & -- \\
C-153T & $134(100.0)$ & $268(100.0)$ & -- \\
CC & $0(0.0)$ & $0(0.0)$ & 0.6141 \\
CT & $0(0.0)$ & $0(0.0)$ & \\
TT & & & 0.4544 \\
$p_{\text {trend }}$ & & & \\
\hline
\end{tabular}

OR: Odds ratio; CI: confidence interval. 'Data adjusted for confounding factors age and gender. bBased on chi-square test without Yates' correction or Fisher exact test when $\mathrm{n}<5$.

Table III. Allelic frequencies for matrix metalloproteinase (MMP7) A-181G and C-153T polymorphisms among patients with pterygium and healthy controls.

\begin{tabular}{lccc}
\hline MMP7 polymorphism & Patients, $\mathrm{n}(\%) \mathrm{n}=268$ & Controls, $\mathrm{n}(\%) \mathrm{n}=536$ & ${\text { Adjusted OR }(95 \% \mathrm{CI})^{\mathrm{a}}}$-Value $^{\mathrm{b}}$ \\
\hline A-181G & & & 1.00 (Reference) \\
Allele A & $245(91.4)$ & $500(93.3)$ & $1.34(0.77-2.32)$ \\
Allele G & $23(8.6)$ & $36(6.7)$ & -- \\
C-153T & $268(100.0)$ & $536(100.0)$ & -- \\
Allele C & $0(0.0)$ & $0(0.0)$ & 0.3389 \\
Allele T & & & \\
\hline
\end{tabular}

OR: Odds ratio; CI: confidence interval. 'Data have been adjusted for confounding factors age and gender. 'based on chi-square test without Yates' correction.

genotypes with pterygium since all individuals investigated carried only $\mathrm{C}$ alleles (Table III).

\section{Discussion}

Under normal conditions, MMP7 is secreted by the cells in the ductal epithelium of glands in the skin, salivary glands, pancreas, glandular epithelium of intestine and reproductive organ, liver, and breast of human body (29). Since MMP7 is responsible for the metabolism of extracellular macromolecules such as casein, type I-V gelatins, fibronectins and proteoglycans (29), it is reasonably hypothesized that hereditary variations of $M M P 7$ may determine personal risk for inflammatory processes, tumor initiation, invasion and metastasis (30). The supporting evidence comes from several sources: a) MMP7 is found to be highly expressed in the 
luminal surface of dysplastic glands in human colorectal cancer (29); b) In clinical practice, MMP7 inhibitors can potentially be applied to control the invasive capacity of cancer cells (30); c) MMP7 has been found to be highly overexpressed in advanced colorectal adenomas and involved in converting colorectal adenomas into a malignant state and facilitating rapid growth of the tumor (31).

In the current study, the results showed that the $G$ allele at MMP7 A-181G was not significantly associated with an increased risk for pterygium (Tables II and III). As far as we are concerned, the present study is the first one to reveal a lack of genotypic contribution of $M M P 7$ promoter genotype to pterygium in a representative population. In literature, the A$181 \mathrm{G}$ genotypes of MMP7 have been examined for their association with various types of cancer, including oral, breast, esophageal, gastric, colorectal, gallbladder, bladder, cervical cancer, leukemia and renal cell carcinoma (28, 32-46). The lack of association of MMP7 genotype with pterygium in the current study, together with those in bladder (34), renal cell (44), oral (35), colorectal (28), and lung (46) cancer in Taiwan supports the concept that MMP7 may influence Taiwanese susceptibility to these diseases via other mechanisms, such as regulation of translation or protein-protein interaction, and simply not through the regulation at the transcriptional level via polymorphic variations in the promoter region. Notably, while the AG genotype at MMP7 promoter A-181G was associated with an OR of $1.22(95 \% \mathrm{CI}=0.91-1.63, p=0.2235)$, the GG genotype had an OR of 2.84 (95\% CI=1.64-7.48, $p=0.0007)$ compared to those carrying the AA wild-type genotype among a very large Taiwan population with 1,232 patients with breast cancer and 1,232 non-cancer controls (32). In addition, boys carrying the $M M P 7 \mathrm{~A}-181 \mathrm{G}$ GG and AG/GG genotypes had 8.79- and 2.04-fold odds ( $p=0.0150$ and 0.0413, respectively) of childhood acute lymphoblastic leukemia compared to those in Taiwan carrying the wild-type AA genotype (33). In our investigated population, the carriers of the $\mathrm{G}$ allele at $M M P 7 \mathrm{~A}-181$ were also non-significantly prone to have a higher pterygium risk (Tables II and III). Thus, from the pilot data we collected here, we still cannot provide any association of MMP7 A-181 with pterygium, while we cannot exclude the possibility that other $M M P 7$ polymorphisms may serve as a biomarker for the prediction of pterygium.

There are several directions for prospective investigations. Firstly, the collection of precious pterygium samples should be continuously conducted to be as representative for the whole population with pterygium as possible. Moreover, validations with larger sample sizes at multiple centers and various populations are needed. Secondly, the genotypephenotype correlation for MMP7 can only be revealed after phenotypic measurements of $M M P 7$ transcripts, protein level and activity with the primarily cultured pterygia and conjunctiva cells from patients with pterygium. Thirdly, any contribution of MMP7 genotype and phenotype to pterygium can be further understood in the stratification of the pterygium population into several subgroups according to their clinical characteristics, such as severity. There are already several classification systems for stratifying patients with pterygium. For example, pterygium can be separated into atrophic, intermediate and fleshy types according to its translucence (47). It is possible to analyze the interaction of MMP7 genotypes and some clinical indices, such as the metastasis status, severity and the level of translucence, in order to understand the role of MMP7 in the etiology and development of pterygium.

In conclusion, the results of this pilot study suggest that neither A-181G nor C-153T genotype of the promoter of MMP7 significantly confer a differential pattern of personal susceptibility to pterygium among Taiwanese. Further investigations elucidating the contribution of the genotypes of other members of $M M P$ s to pterygium initiation and progression are needed and the findings in the current study should be validated in other ethnic populations and larger cohorts.

\section{Conflicts of Interest}

All the Authors have no conflicts of interest to declare.

\section{Authors' Contributions}

Research design: Hu PS and Liao $\mathrm{CH}$; patient and questionnaire summarize: Hu PS and Hsia NY; experiments: Wang YC and Chang WS; statistical analysis: Wu MF, Yang JS and Yu CC; article writing: Tsai CW and Bau DT; review and revision: Chang WS, Tsai CW and Bau DT.

\section{Acknowledgements}

The Authors are grateful to Hsin-Ting Li and Yu-Chen Hsiau for their excellent technical assistance. All the participants including those who were not selected into the control group in the study are appreciated. This study was supported mainly by Changhua Christian Hospital, Changhua, Taiwan to Dr. Hu (grant number: 105-CCH-IRP-144 and 108-CCH-IRP-011). The funders had no any role in study design, data collection, statistical analysis, or decision to publish or preparation of the manuscript.

\section{References}

1 Gazzard G, Saw SM, Farook M, Koh D, Widjaja D, Chia SE, Hong CY and Tan DT: Pterygium in Indonesia: Prevalence, severity and risk factors. Br J Ophthalmol 86: 1341-1346, 2002. PMID: 12446360 . DOI: $10.1136 /$ bjo.86.12.1341

2 Maloof AJ, Ho A and Coroneo MT: Influence of corneal shape on limbal light focusing. Invest Ophthalmol Vis Sci 35: 25922598, 1994. PMID: 8163347.

3 Threlfall TJ and English DR: Sun exposure and pterygium of the eye: A dose-response curve. Am J Ophthalmol 128: 280-287, 1999. PMID: 10511020. DOI: 10.1016/s0002-9394(99)00161-0 
4 de PRJA, Dos Reis GM, KS ES, Rodrigues DA, Gomes MC, Martins JV, da Costa IR, Freitas GA and Moura KK: Analysis of the GSTM1-null polymorphism in patients with pterygium from Goiania, Goias Brazil. Genet Mol Res 14: 6173-6181, 2015. PMID: 26125818. DOI: 10.4238/2015.June.9.3

5 Demurtas P, Orru G, Coni P, Minerba L, Corrias M, Sirigu P, Zucca I, Demurtas E, Maxia C, Piras F, Murtas D, Lai S and Perra MT: Association between the $A C E$ insertion/deletion polymorphism and pterygium in Sardinian patients: A population-based case-control study. BMJ Open 4: e005627, 2014. PMID: 25341451. DOI: 10.1136/bmjopen-2014-005627

6 Peng ML, Tsai YY, Tung JN, Chiang CC, Huang YC, Lee H and Cheng YW: Vascular endothelial growth factor gene polymorphism and protein expression in the pathogenesis of pterygium. Br J Ophthalmol 98: 556-561, 2014. PMID: 24123908. DOI: 10.1136/bjophthalmol-2013-303436

7 Rodrigues FW, Arruda JT, Silva RE and Moura KK: TP53 gene expression, codon 72 polymorphism and human papillomavirus DNA associated with pterygium. Genet Mol Res 7: 1251-1258, 2008. PMID: 19065760.

8 Tsai YY, Bau DT, Chiang CC, Cheng YW, Tseng SH and Tsai FJ: Pterygium and genetic polymorphism of DNA double-strand break repair gene $K U 70$. Mol Vis 13: 1436-1440, 2007. PMID: 17768380 .

9 Bau DT, Chiang CC, Tsai YY, Lee CC, Tsai Y, Lin CC, Tsai CH and Tsai FJ: Evaluation of transforming growth factor and vascular endothelial growth factor polymorphisms in Taiwan Chinese patients with pterygium. Eur J Ophthalmol 18: 21-26, 2008. PMID: 18203080.

10 Tsai YY, Chiang CC, Bau DT, Cheng YW, Lee H, Tseng SH and Tsai FJ: Vascular endothelial growth factor gene 460 polymorphism is associated with pterygium formation in female patients. Cornea 27: 476-479, 2008. PMID: 18434853. DOI: 10.1097/ICO.0b013e3181644581

11 Chiang CC, Tsai YY, Bau DT, Cheng YW, Tseng SH, Wang RF and Tsai FJ: Pterygium and genetic polymorphisms of the DNA repair enzymes XRCC1, XPA, and XPD. Mol Vis 16: 698-704, 2010. PMID: 20431719.

12 Tan DT, Tang WY, Liu YP, Goh HS and Smith DR: Apoptosis and apoptosis related gene expression in normal conjunctiva and pterygium. Br J Ophthalmol 84: 212-216, 2000. PMID: 10655200. DOI: 10.1136/bjo.84.2.212

13 Dushku N, Hatcher SL, Albert DM and Reid TW: p53 expression and relation to human papillomavirus infection in pingueculae, pterygia, and limbal tumors. Arch Ophthalmol 117: 1593-1599, 1999. PMID: 10604662. DOI: 10.1001/ archopht.117.12.1593

14 Wong WW: A hypothesis on the pathogenesis of pterygiums. Ann Ophthalmol 10: 303-308, 1978. PMID: 350121.

15. Seifert $\mathrm{P}$ and Sekundo W: Capillaries in the epithelium of pterygium. Br J Ophthalmol 82: 77-81, 1998. PMID: 9536887. DOI: $10.1136 /$ bjo.82.1.77

16 Di Girolamo N, McCluskey P, Lloyd A, Coroneo MT and Wakefield D: Expression of MMPs and TIMPs in human pterygia and cultured pterygium epithelial cells. Invest Ophthalmol Vis Sci 41: 671-679, 2000. PMID: 10711680.

17 Di Girolamo N, Wakefield D and Coroneo MT: Differential expression of matrix metalloproteinases and their tissue inhibitors at the advancing pterygium head. Invest Ophthalmol Vis Sci 41: 4142-4149, 2000. PMID: 11095607.
18 Solomon A, Li DQ, Lee SB and Tseng SC: Regulation of collagenase, stromelysin, and urokinase-type plasminogen activator in primary pterygium body fibroblasts by inflammatory cytokines. Invest Ophthalmol Vis Sci 41: 2154-2163, 2000. PMID: 10892857.

19 Li DQ, Lee SB, Gunja-Smith Z, Liu Y, Solomon A, Meller D and Tseng SC: Overexpression of collagenase (MMP-1) and stromelysin (MMP-3) by pterygium head fibroblasts. Arch Ophthalmol 119: 71-80, 2001. PMID: 11146729.

20 de Souza AP, Trevilatto PC, Scarel-Caminaga RM, Brito RB and Line SR: MMP-1 promoter polymorphism: association with chronic periodontitis severity in a Brazilian population. J Clin Periodontol 30: 154-158, 2003. PMID: 12622858. DOI: 10.1034/j.1600-051x.2003.300202.x

21 Barille S, Bataille R, Rapp MJ, Harousseau JL and Amiot M: Production of metalloproteinase-7 (matrilysin) by human myeloma cells and its potential involvement in metalloproteinase-2 activation. J Immunol 163: 5723-5728, 1999. PMID: 10553104.

22 Egeblad $M$ and Werb $Z$ : New functions for the matrix metalloproteinases in cancer progression. Nat Rev Cancer 2: 161-174, 2002. PMID: 11990853. DOI: 10.1038/nrc745

23 Wilson CL and Matrisian LM: Matrilysin: an epithelial matrix metalloproteinase with potentially novel functions. Int $\mathrm{J}$ Biochem Cell Biol 28: 123-136, 1996. PMID: 8729000.

24 Haro H, Crawford HC, Fingleton B, Shinomiya K, Spengler DM and Matrisian LM: Matrix metalloproteinase-7-dependent release of tumor necrosis factor-alpha in a model of herniated disc resorption. J Clin Invest 105: 143-150, 2000. PMID: 10642592. DOI: $10.1172 / \mathrm{JCI} 7091$

25 Di Girolamo N, Coroneo MT and Wakefield D: Active matrilysin (MMP7) in human pterygia: Potential role in angiogenesis. Invest Ophthalmol Vis Sci 42: 1963-1968, 2001. PMID: 11481258.

26 Kato N, Shimmura S, Kawakita T, Miyashita H, Ogawa Y, Yoshida S, Higa K, Okano $\mathrm{H}$ and Tsubota K: Beta-catenin activation and epithelial-mesenchymal transition in the pathogenesis of pterygium. Invest Ophthalmol Vis Sci 48: 15111517, 2007. PMID: 17389479. DOI: 10.1167/iovs.06-1060

$27 \mathrm{Hu}$ PS, Chang WS, Chou AK, Hsia NY, Hung YW, Lin CW, Wu CW, Huang CY, Wu MF, Liao CH, Tsai CW, Bau DT and Gong CL: The association of MMP-8 genotypes with pterygium. In Vivo 32: 41-46, 2018. PMID: 29275297. DOI: 10.21873/invivo. 11202

28 Yueh TC, Wu CN, Hung YW, Chang WS, Fu CK, Pei JS, Wu MH, Lai YL, Lee YM, Yen ST, Li HT, Tsai CW and Bau DT: The contribution of $M M P 7$ genotypes to colorectal cancer susceptibility in Taiwan. Cancer Genomics Proteomics 15: 207212, 2018. PMID: 29695403. DOI: $10.21873 / \operatorname{cgp} .20079$

29 Yokoyama Y, Grunebach F, Schmidt SM, Heine A, Hantschel M, Stevanovic S, Rammensee HG and Brossart P: Matrilysin (MMP7) is a novel broadly expressed tumor antigen recognized by antigen-specific T-cells. Clin Cancer Res 14: 5503-5511, 2008. PMID: 18765542. DOI: 10.1158/1078-0432.CCR-07-4041

30 Edman K, Furber M, Hemsley P, Johansson C, Pairaudeau G, Petersen J, Stocks M, Tervo A, Ward A, Wells E and Wissler L: The discovery of MMP7 inhibitors exploiting a novel selectivity trigger. ChemMedChem 6: 769-773, 2011. PMID: 21520417. DOI: $10.1002 / \mathrm{cmdc} .201000550$

31 Qasim BJ, Ali HH and Hussein AG: Immunohistochemical expression of matrix metalloproteinase-7 in human colorectal 
adenomas using specified automated cellular image analysis system: a clinicopathological study. Saudi J Gastroenterol 19: 23-27, 2013. PMID: 23319034. DOI: 10.4103/13193767.105916

32 Chou AK, Hsiao CL, Shih TC, Wang HC, Tsai CW, Chang WS, Liu LC, Way TD, Chung JG and Bau DT: The contribution of matrix metalloproteinase-7 promoter genotypes in breast cancer in Taiwan. Anticancer Res 37: 4973-4977, 2017. PMID: 28870920. DOI: 10.21873/anticanres.11908

33 Pei JS, Chou AK, Hsu PC, Tsai CW, Chang WS, Wu MF, Wu MH, Hsia TC, Cheng SP and Bau DT: Contribution of matrix metalloproteinase-7 genotypes to the risk of non-solid tumor, childhood leukemia. Anticancer Res 37: 6679-6684, 2017. PMID: 29187444. DOI: $10.21873 /$ anticanres.12126

34 Liao CH, Chang WS, Tsai CW, Hu PS, Wu HC, Hsu SW, Chen GL, Yueh TC, Shen TC, Hsia TC and Bau DT: Association of matrix metalloproteinase-7 genotypes with the risk of bladder cancer. In Vivo 32: 1045-1050, 2018. PMID: 30388078. DOI: 10.21873/invivo. 11345

35 Shih LC, Li CH, Sun KT, Chen LY, Hsu CL, Hung YW, Wu CN, Hsia TC, Shen TC, Chang WS, Shih TC, Tsai CW and Bau DT: Association of matrix metalloproteinase-7 genotypes to the risk of oral cancer in Taiwan. Anticancer Res 38: 2087-2092, 2018. PMID: 29599326. DOI: 10.21873/anticanres.12448

36 Malik MA, Sharma KL, Zargar SA and Mittal B: Association of matrix metalloproteinase-7 $(-181 \mathrm{~A}>\mathrm{G})$ polymorphism with risk of esophageal squamous cell carcinoma in Kashmir Valley. Saudi J Gastroenterol 17: 301-306, 2011. PMID: 21912055. DOI: 10.4103/1319-3767.84480

37 Fang WL, Liang WB, Gao LB, Zhou B, Xiao FL and Zhang L: Genetic polymorphisms in matrix metalloproteinases -1 and -7 and susceptibility to gastric cancer: An association study and meta-analysis. Iran J Allergy Asthma Immunol 12: 203-210, 2013. PMID: 23893803.

38 Moreno-Ortiz JM, Gutierrez-Angulo M, Partida-Perez M, Peregrina-Sandoval J, Ramirez-Ramirez R, Muniz-Mendoza R, Suarez-Villanueva S, Centeno-Flores M, Maciel-Gutierrez V, Cabrales-Vazquez JE and Ayala-Madrigal ML: Association of $M M P 7-181 \mathrm{~A} / \mathrm{G}$ and $M M P 13-77 \mathrm{~A} / \mathrm{G}$ polymorphisms with colorectal cancer in a Mexican population. Genet Mol Res 13: 3537-3544, 2014. PMID: 24615104. DOI: 10.4238/2014. February.14.1

39 Sharma KL, Misra S, Kumar A and Mittal B: Higher risk of matrix metalloproteinase (MMP-2, 7, 9) and tissue inhibitor of metalloproteinase (TIMP-2) genetic variants to gallbladder cancer. Liver Int 32: 1278-1286, 2012. PMID: 22621753. DOI: 10.1111/j.1478-3231.2012.02822.x
40 Wieczorek E, Reszka E, Wasowicz W, Grzegorczyk A, Konecki $\mathrm{T}$, Sosnowski $\mathrm{M}$ and Jablonowski Z: $M M P 7$ and $M M P 8$ genetic polymorphisms in bladder cancer patients. Cent European J Urol 66: 405-410, 2014. PMID: 24757528. DOI: 10.5173/ ceju.2013.04.art3

41 Xie B, Zhang Z, Wang H, Chen Z, Wang Y, Liang H, Yang G, Yang $X$ and Zhang $\mathrm{H}$ : Genetic polymorphisms in MMP 2, 3, 7, and 9 genes and the susceptibility and clinical outcome of cervical cancer in a Chinese Han population. Tumour Biol 37: 4883-4888, 2016. PMID: 26526578. DOI: 10.1007/s13277-0154204-6

42 Lievre A, Milet J, Carayol J, Le Corre D, Milan C, Pariente A, Nalet B, Lafon J, Faivre J, Bonithon-Kopp C, Olschwang S, Bonaiti-Pellie C and Laurent-Puig P: Genetic polymorphisms of $M M P 1, M M P 3$ and $M M P 7$ gene promoter and risk of colorectal adenoma. BMC Cancer 6: 270, 2006. PMID: 10.1186/14712407-6-270. DOI: 10.1186/1471-2407-6-270

43 Woo M, Park K, Nam J and Kim JC: Clinical implications of matrix metalloproteinase-1, $-3,-7,-9,-12$, and plasminogen activator inhibitor-1 gene polymorphisms in colorectal cancer. $\mathbf{J}$ Gastroenterol Hepatol 22: 1064-1070, 2007. PMID: 17608852. DOI: $10.1111 / \mathrm{j} .1440-1746.2006 .04424 . x$

44 Liao CH, Chang WS, Hu PS, Wu HC, Hsu SW, Liu YF, Liu SP, Hung HS, Bau DT and Tsai CW: The contribution of $M M P 7$ promoter polymorphisms in renal cell carcinoma. In Vivo 31: 631-635, 2017. PMID: 28652430. DOI: 10.21873/invivo.11104

45 Vairaktaris E, Serefoglou Z, Yapijakis C, Vylliotis A, Nkenke E, Derka S, Vassiliou S, Avgoustidis D, Neukam FW and Patsouris E: High gene expression of matrix metalloproteinase-7 is associated with early stages of oral cancer. Anticancer Res 27: 2493-2498, 2007. PMID: 17695544.

46 Chen GL, Shen TC, Chang WS, Tsai CW, Li HT, Chuang CL, Lai YL, Yueh TC, Hsia TC, Wang SC and Bau DT: The contribution of $M M P 7$ promoter polymorphisms to Taiwan lung cancer susceptibility. Anticancer Res 38: 5671-5677, 2018. PMID: 30275186. DOI: 10.21873/anticanres.12903

47 Kurt A, Kilic R, Tad M and Polat OA: YKL-40 expression in pterygium: A potential role in the pathogenesis. Int Ophthalmol 39: 1445-1450, 2019. PMID: 29922975. DOI: 10.1007/s10792018-0957-4

Received September 15, 2019

Revised October 5, 2019

Accepted October 10, 2019 